\title{
The Influence of Religion, Liberalization and Emotionalism on Consumer Behaviour: Evidence from The Northern Nigeria.
}

\author{
Elisa Ehinmilorin \\ Westcliff University Irvine, Department of Business Administration, \\ 17877 Von Karman Avenue \#400, Irvine, California 92614. \\ Email: e.ehinmilorin.300@westcliff.edu
}

\begin{abstract}
Consumers' choices are usually influenced by religious beliefs, values and emotionalism. The study examined the influence of religion, liberalization and emotionalism on consumer behaviour in Northern Nigeria. Convenient sampling technique was adopted in selecting a total number of 288 respondents who provided requisite data for the study. The study was based on survey design and employed descriptive and inferential statistics (Chisquare) in analyzing data gotten from respondents. The result of the descriptive statistics revealed that majority of the respondents supported the view that religion, liberalization and emotionalism have high and very high influence on consumer behaviour in Northern Nigeria. Accordingly, the study formulated three relevant hypotheses which were tested at the $5 \%$ level of significance. The findings of the study revealed that at the $5 \%$ level of significance, religion, liberalization and emotionalism had statistically significant influence on consumer behaviour in Northern Nigeria. This was based on the fact that the calculated $\mathrm{X}^{2}$ was greater than the table value of $\mathrm{X}^{2}$ at the $5 \%$ level of significance. Based on the findings of the study, it was concluded that religious affiliations, emotional attachment and liberalization are significant determinants of the level of variation in consumer behaviour in Northern Nigeria. Therefore, the study recommended for more understanding of the effect of religion, liberalization and emotionalism on consumer behaviour by firms and organizations in order to ensure that its products and services in Northern Nigeria become appealing to the inhabitants.
\end{abstract}

Keyword: Religion, Liberalization, Emotionalism, Consumer Behaviour

DOI: $10.7176 / \mathrm{JMCR} / 82-05$

Publication date:November $30^{\text {th }} 2021$

\section{Introduction}

Religion is a major factor which influences the consumption pattern and behavior of consumers in different regions. Distinct religion creates distinct values and perception on individuals which goes down to affect most decisions they make in life especially that of consumption. Furthermore, apart from religion, other issues of liberalization and emotionalism are factors which are likely to exert great influence on the decisions of consumers regarding what to and what not to purchase. Just like other regions, the Northern region of Nigeria is not excluded from this. Northern Nigeria is categorically a multi-religious region despite having majority of its inhabitants as Muslims. This goes to show that religion is a major influencer of decisions made by consumers in the north. Generally, the goal of a consumer is the maximization of his utility subject to his income constraint. This goes down to show that a consumer wants value for his income and such value must be consistent with his personal value. As pointed out by Kotler et al. (2009), a lot of factors are responsible for the distinct behavior of consumers in the $21^{\text {st }}$ century. This can however, not be attributed to religion alone or to any single factor but rather to a conglomeration of factors. Religion according to Karl Marx (1883) is the opium of the people. An understanding of consumer behavior is important for being able to deduce factors which influence such behavior. Consumer behavior is influenced by lots of factors which generally makes it complex to decipher or understand. Therefore, in the attempt at understanding the behavioural patterns of consumers it becomes confusing to what approach is best. This has resulted in several conflicting views about the behavioural pattern of consumers.

In support of this argument, Tsang et al. (2004) opined that understanding consumer behavior is simply understanding the various factors that influence consumer behavior. In looking at the aspect of religion, each religion has its likes and dislike. In common parlance it can be viewed as; “another man's meat is another man's poison." Therefore, what a particular religion could tolerate others might not. Similarly, according to Mbah (2000), liberalization affects the behavioural pattern of consumers. Liberalization refers to the tendency of being easily influenced by new products or new ways of doing things. In his study Yousaf et al. (2013) noted that the extent of liberalization affects the behavioural pattern of consumers. When consumers are liberal, they tend to exhibit astute flexibility in consumption. Therefore, they do not oppose consumption behavior distinct from that of their tradition or culture as the case may be. In this sense consumers are regarded as free agents willing to adjust to new ideas and ways of doing things. As pointed out by Quoquab et al. (2000), consumption behavior with liberalization is substantially distinct from that without liberalization. This shows that when consumers are not liberal, it becomes easy to predict their pattern of consumption. Such consumers are not influenced by new ideas or products because 
they hold their traditions, and values in high esteem. This kind of consumption behavior is characteristics of most Muslims. It is a known fact that Muslims do not eat pork as their religion considers it unclean. Therefore, liberal Muslims will always maintain such ideology while the ones being liberal can easily make adjustments. In support of this Yousaf et al. (2013) observed that despite all other factors which exert great influence on the behavioural patterns of consumers, liberalization is highly fundamental. The extent of liberalization characteristics of a consumer, determines his acceptance or rejection of even his religious beliefs. The more liberal a consumer is, the more he tends to refute the claims and precepts of his religion while adjusting to new developments.

Furthermore, in considering the aspect of emotionalism, the emotion of consumers influences their behavioural patterns. As pointed out by White (1997) when a consumer develops an emotional attachment to a particular product, he tends to always consume such product without considering other alternatives. Marketing researchers (Mbah 2000, Singh et al. 2005 and Mathras et al., 2016) noted that the functional magnetic resonance imaging (FMRI) illustrates how brands are evaluated by consumers through the use of personal feelings, perceptions and experiences which all comprise primary emotional characteristics rather than basic information about the product. This points to the fact that when emotional attachment is developed by consumers, attributes, characteristics, facts and features of other brands and product no longer matter to them. In support of this argument, researchers (Kotler et al. 2009, Agarwala et al. 2019 and Quoquab et al. 2017) observed that consumer loyalty is formed when consumers show positive emotions towards products or brands. Emotions therefore form the basis for brand attachment of organizational products and services. As pointed out by Schiffman et al. (1999), White 1997 and Mathras et al. (2016) emotional attachment towards products and brands is fundamental to improving consumer engagements. Organizational performance is improved when consumers form emotional attachment to towards its products and brands. In this way, most organizations invest hugely in improving consumer engagements through emotional attachments. Research shows that emotional attachments towards products influences sales better than rational thoughts of consumers. In their work on brand performance, researchers (Kotler 2009, Yousaf et al. 2013 and Tsang et al, 2007) noted that brands are nothing beyond products given a mental and emotionally driven representation in the consumer's mind. Therefore, emotional attachment might not be developed through firms' actions or activities of advertising but rather through physical product development (White 1997, Mathras et al. 2016 and Yousaf et al. 2013). This points to the fact that visual imagery, effective packaging strategy and attractive displays are major approaches likely to create emotional attachment towards the product.

However, emotional attachment which is a fundamental determinant of consumers behavioural pattern is explained by various theories of consumer behavior. As noted by researchers (Kotler et al. Schiffman et al.1999, and Singh 2005) the revealed preference theory offers a robust and comprehensive explanation of the impact of emotional attachment on the behavioural pattern of consumers. The influence of emotions on decisions, judgments and evaluations of consumers has long been considered important to the attainment of organizations goals and objectives. Notwithstanding, Wilson (2000,) and Swimberghe et al. (2017) noted that consumers could display negative or positive emotions about products. This indicates that when a consumer displays negative emotional attachment towards a product or brand, it becomes substantially difficult buying such product irrespective of the amount of advertising or any other marketing strategy employed by firms. Conversely, once positive emotional attachment is formed, consumers are willing to buy such product even at higher prices. This situation has made various researchers note that emotional attachment is a factor which blinds consumers and stops them from reasoning or being rational.

Factors such as religion, liberalization and emotionalism have been noted to influence consumers' buying behavior in several nations of the world. Therefore, given the above backdrop, this study seeks to evaluate empirically the influence of religion, liberalization and emotionalism on consumer behavior in the Northern Region of Nigeria.

\section{Objectives of the study}

i. To examine the influence of religion on consumer behaviour in Northern Nigeria.

ii. To examine the influence of liberalization on consumer behaviour in Northern Nigeria.

iii. To examine the influence of emotionalism on consumer behaviour in Northern Nigeria

Research Hypothesis

$\mathbf{H}_{01}$ Religion does not significantly influence consumer behaviour in Northern Nigeria.

Ho2 Liberalization does not significantly influence consumer behaviour in Northern Nigeria.

$\mathbf{H}_{03}$ Emotionalism does not significantly influence consumer behaviour in Northern Nigeria.

\section{Literature Review}

Researchers (Singh 2005, Kotler et al. 2009, and Agarwala et al. 2019) noted that religion influences consumers' 
demand for various products. Essentially, as noted by them one of the ways religion impact consumers buying decision is through influencing seasonal desire for products. During Christmas period various Christmas products are highly demanded for by Christians. This increases the demand for such commodities during this season of the year. The same can as well be said for their Muslim counterpart. During the Islamic celebration period known as Eid-el Malud, some products are being demanded by Muslims in high quantity. Therefore, the demand for such products as well as their prices tends to increase substantially during such season of the year. Therefore, religion is a fundamental determinant of consumer behaviour. In support of this argument, Mathras et al (2016) noted that one could predict the consumption pattern of a group if their religious affiliations were ascertained. Consumption patterns of groups are offspring of their religious affiliations. One would not expect the consumption behaviour of group composed of only Christians to be the same as that of a group composed of both Christians and Muslims. Therefore, organizations research about religious affiliations of societies and regions in order to know exactly what to produce within such society or region.

Just like religion, liberalization influences consumer behaviour. However, there is insufficient evidence to support this argument. Notwithstanding, researchers (Kotler et al. 2009, Agarwala et al. 2019 and Quoquab et al. 2017) noted that when consumers are free to make choices for themselves their consumer behaviour differs significantly from when they were constrained by dogmatic belief and values. As noted by Wilson (2000), Singh (2005) and Mathras et al. (2016), liberalization refers to the ability of consumers to make choices not subject to cultural servitude or other religious or emotional attachment. When a consumer is not influenced by religious, emotional and cultural values, such a consumer is said to be entirely free to make choices for himself. Therefore, liberalization influences the pattern of consumption of consumers. Accordingly, emotionalism dictates the pattern of consumption of consumers. When emotions are formed about a product or service product loyalty is formed and it becomes difficult switching to alternative products.

Given the above, empirical studies on religion, emotionalism and consumer behaviour are enormous. However, there is lack of empirical studies on the influence of liberalization on consumer behaviour. Researchers (White 1997, Wilson 2000 and Quoquab et al. 2017) examined the relationship between the duration of consumer and the emotional dimensions of consumers. The study revealed that emotional dimensions of pleasure and arousal which were employed based on Russell et al.'s (1989) to measure emotional pleasure significantly influence consumer experience and behaviour. In another study, Agarwala et al. (2019) stated that religion through its associated impact on values, beliefs and identity of consumers influence the choice people make. He further noted that the effect of religion on consumer behaviour could be positive or negative as the case may be. Marketing researchers (Tsang et al. 2004, Yousaf et al. 2013 and Mathras et al. 2016) supported this view when they opined those consumers may be motivated to consume more of a particular product and less of another product due to their religious affiliations. Therefore, by increasing the consumption of some commodities and reducing the consumption of the others religion leads to the creation of attitudes towards various commodities.

Theoretical underpinnings for consumer behaviour include the theory of reasoned action (TRA) and the revealed preference theory (RPT). The theory of reasoned action has been employed by several researchers in explaining dynamics of consumer behaviour. However, the model has been criticized in many ways for not adequately explaining real factors influencing consumer behaviour aside from its proposed psychological factors. On the other hand, the revealed preference theory is a theory of consumer behaviour which assumes that in indicating preference for a particular basket of good, the consumer is consistent, transitive and rational in his choices (White, 1997, Schiffman et al. 1999 and Agarwala et al. 2019). Overall, the crux of the theory rests on the fact that if a consumer buys a particular product when other products are available to him, he shows preference for such good. In this sense, the consumer is said to make rational choices which implies that he always wishes to maximize his satisfaction subject to his budget constraint. Also, the consumer is consistent in his choices and transitive implying that he will always make the same set of choices when under the same condition.

\section{Methodology}

The study employs the survey research design. Descriptive and inferential statistical methods of analysis were employed as analytical techniques. The descriptive analysis was done through the use of tables, percentages and graphs. However, the inferential statistical investigation was carried through the use of Chi-square $\left(\mathrm{X}^{2}\right)$ technique which was considered best for the nature of the investigation. The Chi-square $\left(\mathrm{X}^{2}\right)$ technique was employed in testing the hypotheses formulated in the study. The target population for this study is the Northern Region of Nigeria. Northern Nigeria has a population estimate of 160 million (source: 2018 provisional population census figures). The Northern Region of Nigeria consists of 3 geo-political zones which are: North Central, North East and North West. However, a sample size of 318 consumers from across the 3 geo-political zones was used for the study. The study employed the convenient sampling technique in selecting the respondents which were selected based on accessibility. The study developed a questionnaire titled "Influence of religion, liberalization and 
emotionalism on consumer behaviour questionnaire." The questionnaire was divided into two parts such that the first part consists of questions regarding the demographic characteristics of the respondents while the second part contained questions on the influence of religion, liberalization and emotionalism on consumer behaviour. The Likert scale of measurement technique was employed for the study. The measurement was done on the basis of very high influence $(\mathrm{VHI})=5$, high influence $(\mathrm{HI})=4$, moderate influence $(\mathrm{MI})=3$, low influence $(\mathrm{LI})=2$, very low influence $(\mathrm{VLI})=1$.

\section{Results}

This section consists of the presentation of data and analysis of the study. In the course of distribution and collection of questionnaires, out of the 318 questionnaires distributed, a total number of 288 was perfectly filled and returned. This is illustrated below;

Table 1: Questionnaire Recovery Analysis

\begin{tabular}{|l|l|l|}
\hline Particulars & Frequency & Percent (\%) \\
\hline Returned & 288 & 90.6 \\
\hline Not returned & 30 & 9.4 \\
\hline Total & $\mathbf{3 1 8}$ & $\mathbf{1 0 0}$ \\
\hline
\end{tabular}

Source: Field Survey, 2021

Table 2: Demographics

Item Characteristics No. of Respondents Percentage

Gender

$\begin{array}{lll}\text { Male } & 135 & 46.9 \\ \text { Female } & 153 & 53.1 \\ \text { Total } & 288 & 100\end{array}$

Age

$18-24$

25-35

34

11.8

$36-45$

31.6

46-55

21.2

Above 56

14.9

Total

20.5

100

Religion

Christianity

Islam

18.1

Total

81.9

Primary

Secondary

Level of Education

Diploma

26.4

Degree

Postgraduate

Total

Single

Marital Status

Married

Divorced

Total

$\begin{array}{ll}28 & 100 \\ 51 & 100\end{array}$

$51 \quad 17.7$

$223 \quad 77.4$

$14 \quad 4.9$

\section{Source: Researcher's Computation}

\subsection{Objective One: To examine the influence of religion on consumer behaviour in Northern Nigeria.}

First, this study sought to determine if religion impacts consumer behavior in Northern Nigeria. To do so, researchers used the Likert scale statistical approach, asking participants to rate their agreement with the concept that religion influences consumer behavior in Northern Nigeria. This Likert scale approach was set up in such a way that respondents may choose from one to five alternatives, including very low influence, low influence, moderate influence, strong influence, and very high influence. The figure below depicts the responses of all respondents. 


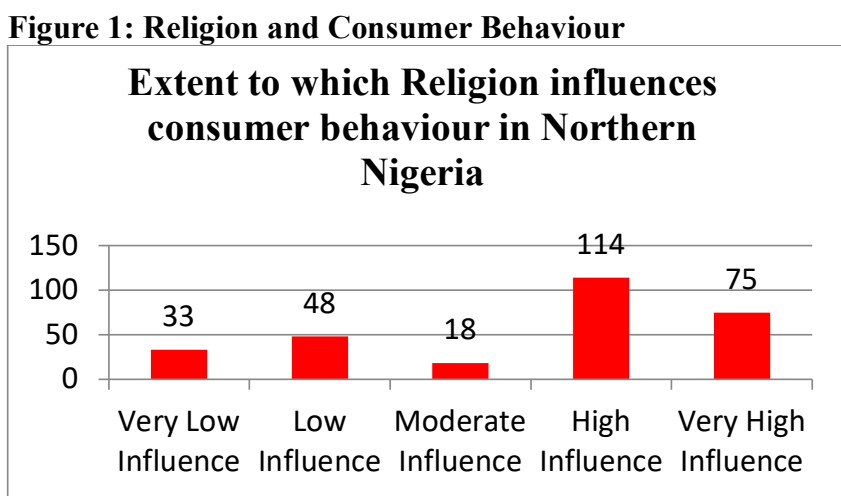

Source: Researcher's Computation

From the graph above, 33 persons representing $11.5 \%$ of the total responses chose the very low influence option. Also, 48 persons representing $16.7 \%$ of the total responses chose the low influence option. 18 persons representing $6.2 \%$ of the total responses chose the moderate influence option. 114 persons representing $39.6 \%$ of the total responses chose the high influence while 75 persons representing $26 \%$ of the total responses chose the very high influence option. Overall, given that majority of the responses noted that religion has a high and very high influence on consumer behaviour in Northern Nigeria. Our conclusion is on that basis.

5.2 Objective Two: To examine the influence of Liberalization on consumer behaviour in Northern Nigeria. In order to tackle the second objective of this study we present the graphical representation of the responses below;

Figure 2: Liberalization and Consumer Behaviour

\section{Extent to which Liberalization Influences Consumer Behaviour in Northern Nigeria}

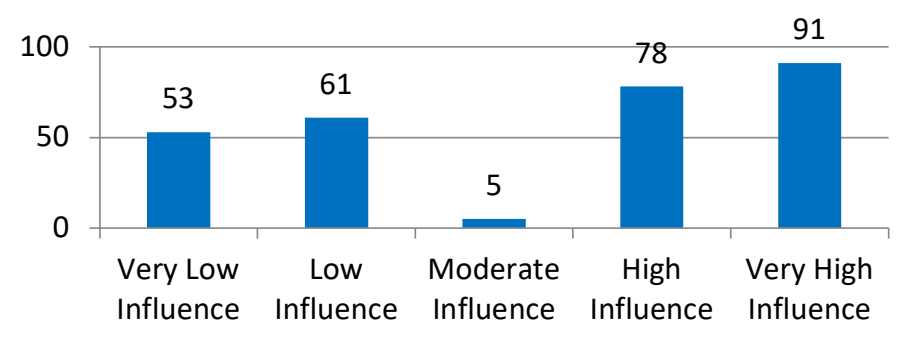

Source; Researcher's Computations

From the graph above, 53 persons representing $18.4 \%$ of the total responses chose the very low influence option. Also, 61 persons representing $21.2 \%$ of the total responses chose the low influence option. 5 persons representing $1.7 \%$ of the total responses chose the moderate influence option. 78 persons representing $27.1 \%$ of the total responses chose the high influence while 91 persons representing $31.6 \%$ of the total responses chose the very high influence option. Overall, given that majority of the responses noted that liberalization has a high and very high influence on consumer behaviour in Northern Nigeria. Our conclusion is on that basis.

5.3 Objective Three: To examine the influence of Emotionalism on consumer behaviour in Northern Nigeria. In order to tackle the third objective of this study we present the graphical representation of the responses below; 


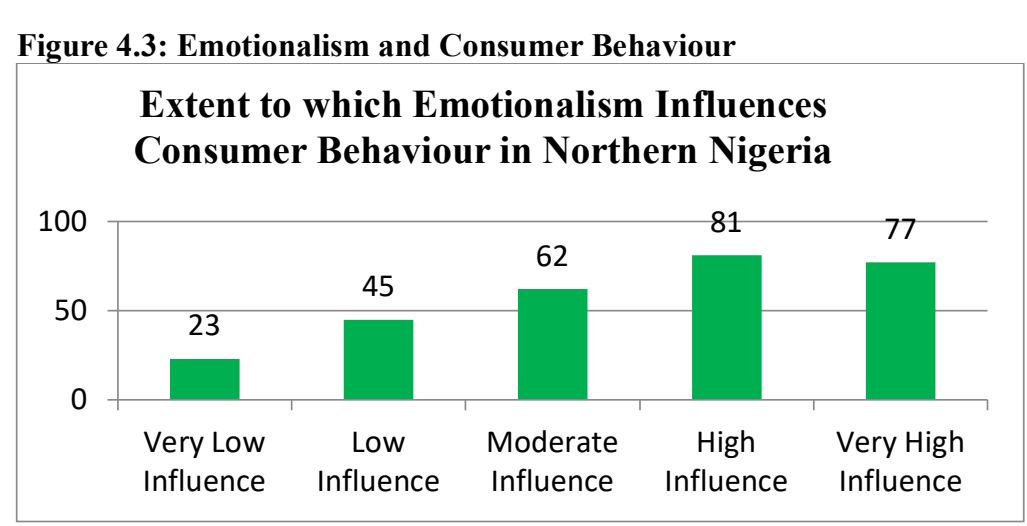

\section{Source; Researcher's Computations}

From the graph above, 23 persons representing $8 \%$ of the total responses chose the very low influence option. Also, 45 persons representing $15.6 \%$ of the total responses chose the low influence option. 62 persons representing $21.5 \%$ of the total responses chose the moderate influence option. 81 persons representing $28.1 \%$ of the total responses chose the high influence while 77 persons representing $26.7 \%$ of the total responses chose the very high influence option. Overall, given that majority of the responses noted that emotionalism has a high and very high influence on consumer behaviour in Northern Nigeria. Our conclusion is on that basis.

\section{Test of Hypothesis}

\section{Restatement of Hypothesis One}

$\mathbf{H}_{01}$ : Religion does not significantly influence consumer behaviour in Northern Nigeria.

To test this hypothesis statement, table 3 and table 4 were used.

Table 3: Religion and Consumer Behaviour

\begin{tabular}{|l|l|l|l|l|l|l|}
\hline Items & Q1 & Q2 & Q3 & Q4 & Total & Mean (E) \\
\hline VHI & $110(\mathrm{~A})$ & $99(\mathrm{~B})$ & $128(\mathrm{C})$ & $81(\mathrm{D})$ & $\mathbf{4 1 8}$ & $\mathbf{1 0 4 . 5}$ \\
\hline HI & $94(\mathrm{E})$ & $123(\mathrm{~F})$ & $77(\mathrm{G})$ & $92(\mathrm{H})$ & $\mathbf{3 8 6}$ & $\mathbf{9 6 . 5}$ \\
\hline MI & $43(\mathrm{I})$ & $39(\mathrm{~J})$ & $58(\mathrm{~K})$ & $72(\mathrm{~L})$ & $\mathbf{2 1 2}$ & $\mathbf{5 3}$ \\
\hline LI & $23(\mathrm{M})$ & $16(\mathrm{~N})$ & $9(\mathrm{O})$ & $37(\mathrm{P})$ & $\mathbf{8 5}$ & $\mathbf{2 1 . 2 5}$ \\
\hline VLI & $18(\mathrm{Q})$ & $11(\mathrm{R})$ & $16(\mathrm{~S})$ & $6(\mathrm{~T})$ & $\mathbf{5 1}$ & $\mathbf{1 2 . 7 5}$ \\
\hline Total & $\mathbf{2 8 8}$ & $\mathbf{2 8 8}$ & $\mathbf{2 8 8}$ & $\mathbf{2 8 8}$ & $\mathbf{1 1 5 2}$ & \\
& & & & & & \\
\hline
\end{tabular}

Source: Field Survey, 2021

Table 4: Chi-square calculation. Contingency Table

\begin{tabular}{|c|c|c|c|}
\hline Items & Observed values $(0)$ & Expected values (E) & Chi-square $X^{2}=\frac{(\mathrm{O}-\mathrm{E})^{2}}{E}$ \\
\hline $\mathbf{A}$ & 110 & 104.5 & 0.29 \\
\hline B & 99 & 104.5 & 0.29 \\
\hline $\mathbf{C}$ & 128 & 104.5 & 5.28 \\
\hline D & 81 & 104.5 & 5.28 \\
\hline $\mathbf{E}$ & 94 & 96.5 & 0.06 \\
\hline $\mathbf{F}$ & 123 & 96.5 & 7.28 \\
\hline $\mathbf{G}$ & 77 & 96.5 & 3.94 \\
\hline $\mathbf{H}$ & 92 & 96.5 & 0.21 \\
\hline $\mathbf{I}$ & 43 & 53 & 1.89 \\
\hline $\mathbf{J}$ & 39 & 53 & 3.70 \\
\hline $\mathbf{K}$ & 58 & 53 & 0.47 \\
\hline $\mathbf{L}$ & 72 & 53 & 6.81 \\
\hline $\mathbf{M}$ & 23 & 21.25 & 0.14 \\
\hline $\mathbf{N}$ & 16 & 21.25 & 1.30 \\
\hline $\mathbf{O}$ & 9 & 21.25 & 7.06 \\
\hline $\mathbf{P}$ & 37 & 21.25 & 11.67 \\
\hline Q & 18 & 12.75 & 2.16 \\
\hline
\end{tabular}




\begin{tabular}{|l|l|l|l|}
\hline $\mathbf{R}$ & 11 & 12.75 & 0.12 \\
\hline $\mathbf{S}$ & 16 & 12.75 & 0.83 \\
\hline $\mathbf{T}$ & 6 & 12.75 & 3.57 \\
\hline Total & & & $\mathbf{6 2 . 3 5}$ \\
\hline
\end{tabular}

Source: Field Survey, 2021

Calculated $\mathrm{X}^{2}=62.35$

$\mathrm{X}^{2}$ table value at $5 \%$ level of significance

$\alpha=5 \%=0.05$

d.f. $=(\mathrm{r}-1)(\mathrm{c}-1)$

Where $r=$ number of rows, $C=$ number of columns

$\mathrm{r}=5, \mathrm{c}=4$

$\mathrm{df}=(5-1)(4-1)$

$\mathrm{df}=4 \times 3=12$

$\mathrm{X}^{2}$ table at $5 \%$ level of significance df $12=21.026$

\subsection{Interpretation}

From the analysis above, $\mathrm{X}^{2}$ calculated value is 62.35 while the table $\mathrm{X}^{2}$ value is 21.026 . This shows that the calculated $\mathrm{X}^{2}$ of 62.35 is greater than the table $\mathrm{X}^{2}$ of 21.026

That is, calculated $\mathrm{X}^{2}$ of $62.35>$ table $\mathrm{X}^{2}$ of 21.026

Therefore we reject the first null hypothesis $\left(\mathrm{H}_{01}\right)$, which states that religion has no significant influence on consumer behaviour in Northern Nigeria.

\subsection{Restatement of Hypothesis Two}

$\mathbf{H}_{02}$ : Liberalization does not significantly influence consumer behaviour in Northern Nigeria.

To test this hypothesis statement, table 5 and table 6 were used.

Table 5: Liberalization and Consumer Behaviour

\begin{tabular}{|l|l|l|l|l|l|l|}
\hline Items & Q1 & Q2 & Q3 & Q4 & Total & Mean (E) \\
\hline VHI & $87(\mathrm{~A})$ & $121(\mathrm{~B})$ & $40(\mathrm{C})$ & $77(\mathrm{D})$ & $\mathbf{3 2 5}$ & $\mathbf{8 1 . 2 5}$ \\
\hline HI & $103(\mathrm{E})$ & $54(\mathrm{~F})$ & $67(\mathrm{G})$ & $83(\mathrm{H})$ & $\mathbf{3 0 7}$ & $\mathbf{7 6 . 7 5}$ \\
\hline MI & $73(\mathrm{I})$ & $84(\mathrm{~J})$ & $51(\mathrm{~K})$ & $51(\mathrm{~L})$ & $\mathbf{2 5 9}$ & $\mathbf{6 4 . 7 5}$ \\
\hline LI & $19(\mathrm{M})$ & $28(\mathrm{~N})$ & $98(\mathrm{O})$ & $21(\mathrm{P})$ & $\mathbf{1 6 6}$ & $\mathbf{4 1 . 5}$ \\
\hline VLI & $6(\mathrm{Q})$ & $1(\mathrm{R})$ & $32(\mathrm{~S})$ & $56(\mathrm{~T})$ & $\mathbf{9 5}$ & $\mathbf{2 3 . 7 5}$ \\
\hline Total & $\mathbf{2 8 8}$ & $\mathbf{2 8 8}$ & $\mathbf{2 8 8}$ & $\mathbf{2 8 8}$ & $\mathbf{1 1 5 2}$ & \\
& & & & & & \\
\hline
\end{tabular}

Source: Field Survey, 2021

Table 6: Chi-square calculation. Contingency Table

\begin{tabular}{|l|l|l|l|}
\hline Items & Observed values $(\mathbf{O})$ & Expected values $(\mathbf{E})$ & Chi-square $^{\mathbf{2}}=\frac{(\mathbf{O}-\mathbf{E})^{\mathbf{2}}}{\mathbf{E}}$ \\
\hline $\mathbf{A}$ & 87 & 81.25 & 0.41 \\
\hline $\mathbf{B}$ & 121 & 81.25 & 19.45 \\
\hline $\mathbf{C}$ & 40 & 81.25 & 20.94 \\
\hline $\mathbf{D}$ & 77 & 81.25 & 0.22 \\
\hline $\mathbf{E}$ & 103 & 76.75 & 8.98 \\
\hline $\mathbf{F}$ & 54 & 76.75 & 6.74 \\
\hline $\mathbf{G}$ & 67 & 76.75 & 1.24 \\
\hline $\mathbf{H}$ & 83 & 76.75 & 0.51 \\
\hline $\mathbf{I}$ & 73 & 64.75 & 1.05 \\
\hline $\mathbf{J}$ & 84 & 64.75 & 5.72 \\
\hline $\mathbf{K}$ & 51 & 64.75 & 2.92 \\
\hline $\mathbf{L}$ & 51 & 64.75 & 2.92 \\
\hline $\mathbf{M}$ & 19 & 41.5 & 12.20 \\
\hline $\mathbf{N}$ & 28 & 41.5 & 4.39 \\
\hline $\mathbf{O}$ & 98 & 41.5 & 76.92 \\
\hline $\mathbf{P}$ & 21 & 41.5 & 10.13 \\
\hline $\mathbf{Q}$ & 6 & 23.75 & 13.27 \\
\hline
\end{tabular}




\begin{tabular}{|l|l|l|l|}
\hline $\mathbf{R}$ & 1 & 23.75 & 21.79 \\
\hline $\mathbf{S}$ & 32 & 23.75 & 2.87 \\
\hline $\mathbf{T}$ & 56 & 23.75 & 43.79 \\
\hline Total & & & $\mathbf{2 5 6 . 4 6}$ \\
\hline
\end{tabular}

\section{Source: Field Survey, 2021}

Calculated $\mathrm{X}^{2}=256.46$

$\mathrm{X}^{2}$ table value at $5 \%$ level of significance

$\alpha=5 \%=0.05$

d.f. $=(\mathrm{r}-1)(\mathrm{c}-1)$

Where $\mathrm{r}=$ number of rows, $\mathrm{C}=$ number of columns

$\mathrm{r}=5, \mathrm{c}=4$

$\mathrm{df}=(5-1)(4-1)$

$\mathrm{df}=4 \times 3=12$

$\mathrm{X}^{2}$ table at $5 \%$ level of significance df $12=21.026$

\subsection{Interpretation}

From the analysis above, $\mathrm{X}^{2}$ calculated value is 256.46 while the table $\mathrm{X}^{2}$ value is 21.026 . This shows that the calculated $X^{2}$ of 256.46 is greater than the table $X^{2}$ of 21.026

That is, calculated $\mathrm{X}^{2}$ of $256.46>$ table $\mathrm{X}^{2}$ of 21.026

Therefore, we reject the second null hypothesis $\left(\mathrm{H}_{02}\right)$, which states that liberalization has no significant influence on consumer behaviour in Northern Nigeria.

\subsection{Restatement of Hypothesis Three}

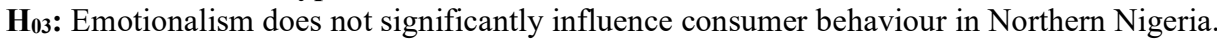

To test this hypothesis statement, table 7 and table 8 were used;

Table 7: Emotionalism and Consumer Behaviour

\begin{tabular}{|l|l|l|l|l|l|l|}
\hline Items & Q1 & Q2 & Q3 & Q4 & Total & Mean (E) \\
\hline VHI & $77(\mathrm{~A})$ & $101(\mathrm{~B})$ & $121(\mathrm{C})$ & $92(\mathrm{D})$ & $\mathbf{3 9 1}$ & $\mathbf{9 7 . 7 5}$ \\
\hline HI & $113(\mathrm{E})$ & $54(\mathrm{~F})$ & $67(\mathrm{G})$ & $59(\mathrm{H})$ & $\mathbf{2 9 3}$ & $\mathbf{7 3 . 2 5}$ \\
\hline MI & $63(\mathrm{I})$ & $84(\mathrm{~J})$ & $51(\mathrm{~K})$ & $44(\mathrm{~L})$ & $\mathbf{2 4 2}$ & $\mathbf{6 0 . 5}$ \\
\hline LI & $29(\mathrm{M})$ & $48(\mathrm{~N})$ & $28(\mathrm{O})$ & $21(\mathrm{P})$ & $\mathbf{1 2 6}$ & $\mathbf{3 1 . 5}$ \\
\hline VLI & $6(\mathrm{Q})$ & $1(\mathrm{R})$ & $21(\mathrm{~S})$ & $72(\mathrm{~T})$ & $\mathbf{1 0 0}$ & $\mathbf{2 5}$ \\
\hline Total & $\mathbf{2 8 8}$ & $\mathbf{2 8 8}$ & $\mathbf{2 8 8}$ & $\mathbf{2 8 8}$ & $\mathbf{1 1 5 2}$ & \\
& & & & & & \\
\hline
\end{tabular}

Source: Field Survey, 2021

Table 8: Chi-square calculation. Contingency Table

\begin{tabular}{|l|l|l|l|}
\hline Items & Observed values $(\mathbf{O})$ & Expected values $(\mathbf{E})$ & Chi-square $^{\mathbf{2}} \mathbf{( \mathbf { O } - \mathbf { E } ) ^ { \mathbf { 2 } }}$ \\
\hline $\mathbf{A}$ & 77 & 97.75 & $\mathbf{E}$ \\
\hline $\mathbf{B}$ & 101 & 97.75 & 0.11 \\
\hline $\mathbf{C}$ & 121 & 97.75 & 5.53 \\
\hline $\mathbf{D}$ & 92 & 97.75 & 0.34 \\
\hline $\mathbf{E}$ & 113 & 73.25 & 21.57 \\
\hline $\mathbf{F}$ & 54 & 73.25 & 5.06 \\
\hline $\mathbf{G}$ & 67 & 73.25 & 0.53 \\
\hline $\mathbf{H}$ & 59 & 73.25 & 2.77 \\
\hline $\mathbf{I}$ & 63 & 60.5 & 0.10 \\
\hline $\mathbf{J}$ & 84 & 60.5 & 9.13 \\
\hline $\mathbf{K}$ & 51 & 60.5 & 1.49 \\
\hline $\mathbf{L}$ & 44 & 60.5 & 4.50 \\
\hline $\mathbf{M}$ & 29 & 31.5 & 0.20 \\
\hline $\mathbf{N}$ & 48 & 31.5 & 8.64 \\
\hline $\mathbf{O}$ & 28 & 31.5 & 0.39 \\
\hline $\mathbf{P}$ & 21 & 31.5 & 3.5 \\
\hline $\mathbf{Q}$ & 6 & 25 & 14.44 \\
\hline
\end{tabular}




\begin{tabular}{|l|l|l|l|}
\hline $\mathbf{R}$ & 1 & 25 & 23.04 \\
\hline $\mathbf{S}$ & 21 & 25 & 0.64 \\
\hline $\mathbf{T}$ & 72 & 25 & 88.36 \\
\hline Total & & & $\mathbf{1 9 4 . 7 4}$ \\
\hline
\end{tabular}

Source: Field Survey, 2021

Calculated $\mathrm{X}^{2}=194.74$

$\mathrm{X}^{2}$ table value at $5 \%$ level of significance

$\alpha=5 \%=0.05$

d.f. $=(\mathrm{r}-1)(\mathrm{c}-1)$

Where $r=$ number of rows, $C=$ number of columns

$\mathrm{r}=5, \mathrm{c}=4$

$\mathrm{df}=(5-1)(4-1)$

$\mathrm{df}=4 \times 3=12$

$\mathrm{X}^{2}$ table at $5 \%$ level of significance df $12=21.026$

5.8 Interpretation

From the analysis above, $\mathrm{X}^{2}$ calculated value is 194.74 while the table $\mathrm{X}^{2}$ value is 21.026 . This shows that the calculated $\mathrm{X}^{2}$ of 194.74 is greater than the table $\mathrm{X}^{2}$ of 21.026

That is, calculated $\mathrm{X}^{2}$ of $194.74>$ table $\mathrm{X}^{2}$ of 21.026

Therefore, we reject the third null hypothesis $\left(\mathrm{H}_{03}\right)$, which states that emotionalism has no significant influence on consumer behaviour in Northern Nigeria.

\section{Discussion}

The findings of the study revealed that religion, liberalization and emotionalism are significant factors influencing the behavioural pattern of consumers in Northern Nigeria. The demographics revealed that majority of the respondents were middle aged individuals, who were predominantly Muslims, married and have below tertiary education. Similarly, the graphical representation of responses revealed that the majority of the respondents supported the view that religion, liberalization and emotionalism have high influence and very high influence on consumer behaviour in Nigeria. This finding is not surprising given the fact that it is in addendum with the findings of other researchers reviewed in the literature. Also, the Chi-square test revealed that at the $5 \%$ level of significance, employing the associated degree of freedom, religion, liberalization and emotionalism were found to have statistically significant impact on consumer behaviour in Nigeria.

\section{Conclusion}

The study investigated the influence of religion, liberalization and emotionalism on consumer behaviour in Northern Nigeria. Research shows that religious affiliations impact on values, beliefs and perceptions of individuals which goes to affect consumption choices they make. Also, when a consumer forms an emotional attachment towards a particular product, he tends to purchase such product even at higher prices and when offered cheaper alternative. In the same vein, when a consumer is free to make choices for himself, he makes those choices devoid of emotions, cultural and religious values. It is on the basis of the above that this study employed the survey design and descriptive and inferential technique in examining the influence of religion, liberalization and emotionalism in Northern Nigeria. Overall, the findings of the study revealed that at the $5 \%$ level of significance, religion, liberalization and emotionalism significantly influence consumption behaviour of Northerners. Therefore, it is concluded that religion, liberalization and emotionalism are significant influencers of consumer behaviour in Northern Nigeria. On that basis, the study recommends for more understanding of the effect of religion, liberalization and emotionalism on consumer behaviour by firms and organizations in order to ensure that its products and services in Nothern Nigeria become appealing to the inhabitants.

\section{References}

Agarwala, R.; Mishra, P.; Singh, R. (2019). Religiosity and consumer behavior: A summarizing review. J. Manag. Spiritual. Relig. 16, 32-54.

Kotler, P. and Keller, K. L. 2009. Marketing Management, New Jersey: Pearson Prentice Hall.

Mbah, C. E. 2000. Marketing Management: Theory and Practice, Lagos: Sivar Industry Limited.

Mathras, D.; Cohen, A.; Mandel, N.; Mick, D.G. 2016. The effects of religion on consumer $\quad$ behavior: A conceptual framework and research agenda. J. Consum. Psychol. 26, 298311. 
Schiffman, L. G. and Kanuk, L. L. 1999. Consumer Behaviour, India: Prentice Hall.

Singh, K. 2005. Questioning Globalization, London: Zed Books.

Swimberghe, K.; Flurry, L.A.; Parker, J.M. 2017. Consumer religiosity: Consequences for activism in the United States. J. Bus. Ethics, 103, 453-467.

Tsang, M.M.; Ho, S.C.; Lian, T.P. 2004. Consumer attitudes toward mobile advertising: an study. Int. J. Elec. Com. 8, 65-78.

Quoquab, F.; Pahlevan, J.; Ramayah, T.M. 2017. Factors affecting consumers' intention to counterfeit product: An empirical study in the Malaysian market. Asia Pac. J. Mark. $837-853$.

White, S. 1997. Marketing Basics, New York: CWL Publishing Enterprises.

Wilson, D. F. 2000. "Why Divide Consumer and Organizational Buyer Behaviour", European Marketing, Vol.34, No.7, pp. 780-796.

Yousaf, S.; Malik, M.S. 2013. Evaluating the influences of religiosity and product involvement consumers. J. Islam. Mark, 4, 163-186.

Journal of

consumer

empirical

Logist., 29

level on the 